\title{
Lead accumulation in extracellular granules detected in the kidney of the bivalve Dosinia exoleta
}

\author{
Susana DARRIBA ${ }^{1, a}$ and Paula SÁNCHEZ-MARÍN ${ }^{2,3, b}$ \\ 1 Technological Institute for the Monitoring of the Marine Environment of Galicia (INTECMAR), Consellería do Medio Rural e do Mar., \\ Vilagarcía de Arousa, Galicia, Spain \\ 2 Laboratorio de Ecoloxía Mariña (LEM), Universidade de Vigo, Vigo, Galicia, Spain \\ 3 Institut national de la recherche scientifique, Centre Eau, Terre et Environnement, Québec, Canada
}

Received 18 September 2012; Accepted 9 November 2012

\begin{abstract}
Populations of the marine molluscan bivalve Dosinia exoleta in Galicia (northwest Spain) present lead $(\mathrm{Pb})$ concentrations above the limit for human consumption. Accordingly, its collection for human consumption was forbidden since 2008. The high bioaccumulation of $\mathrm{Pb}$ in this species is surprising given that $\mathrm{Pb}$ concentrations are not very high in its environment and that other bivalve infaunal species inhabiting the same areas do not show such high $\mathrm{Pb}$ contents. This study reports the discovery and description of extracellular granules present in the kidney tubule lumina of this species. Large granules (20-200 $\mu \mathrm{m}$ ) mainly composed of calcium phosphate represent between 50\% and $75 \%$ of the dry weight of the kidneys. Metal analysis revealed that from 78 to $98 \%$ of the $\mathrm{Pb}$ body burden was present in the kidney, and from $87 \%$ to $92 \%$ of this $\mathrm{Pb}$ within the kidney was contained in metal rich granules. Most of the zinc in these bivalves was also found to be associated with these kidney granules, while other metals, such as copper and cadmium, were associated with other kidney fractions. This study confirms that the high $\mathrm{Pb}$ concentrations observed in $D$. exoleta, and the relationship of $\mathrm{Pb}$ concentration with individual size, are due to the inclusion of $\mathrm{Pb}$ in kidney granules that accumulate in the kidney lumen over the course of the bivalve's life.
\end{abstract}

Keywords: Metal bioaccumulation / Lead uptake / Metal rich granules / Clam / Veneridae / Bivalvia / Atlantic Ocean

\section{Introduction}

The bivalve mollusc Dosinia exoleta (Linnaeus 1758) was once very important as a commercial species harvested in the Galician Rías (NW Spain). Until 2005, its production was over one thousand tonnes per year (Anonymous 2012), but in 2006 the exploitation of this marine resource was partially interrupted due to the high $\mathrm{Pb}$ concentrations detected in its flesh, which were higher than the $1.5 \mu \mathrm{g} \mathrm{g}^{-1}$ wet weight (ww)- limit established by the European Commission for human consumption (Anonymous 2006). Then, in 2008, the collection of this species for human consumption was prohibited in Galicia.

Studies of metal concentrations in other bivalve molluscs from the Galician Rías (Besada et al. 2002; Beiras et al. 2003c; Besada and González-Quijano 2003; Saavedra et al. 2004; Blanco et al. 2008; Besada et al. 2011) showed lower levels of $\mathrm{Pb}$ concentrations than those detected in D. exoleta (SánchezMarín and Beiras 2008). Galician Rías have only a low level of pollution, mainly restricted to localised areas (Beiras et al. 2003a; Beiras et al. 2003b; Prego and Cobelo-García 2003).

\footnotetext{
${ }^{a}$ Corresponding author: sdarriba@intecmar.org

b Corresponding author: paula.sanchez-marin@ete.inrs.ca
}

The high $\mathrm{Pb}$ accumulation by large individuals of $D$. exoleta from the Ría de Arousa was unusual given the low level of $\mathrm{Pb}$ pollution in this Ría and this was interpreted as a particularity of this species (Sánchez-Marín and Beiras 2008).

Metal accumulation by bivalves and other biota is influenced by several biological and environmental factors (size, age, season, reproductive stage, etc.). Sanchez-Marín and Beiras (2008) found a positive relationship between size and metal accumulation in $D$. exoleta. It was observed that larger individuals $(>40 \mathrm{~mm}$ ) could contain much higher concentrations of $\mathrm{Pb}$ than smaller ones. This pattern is often observed in bivalves that accumulate metals in metal concretions, where the metal is accumulated as a storage compartment throughout the animals' lives, so that larger -and older- animals usually contain more granules (Brown 1982; Wallace et al. 2003). The ability of bivalve molluscs to accumulate metals, such as lead, copper, cadmium and zinc is well known, but the mechanisms of detoxification are not well understood (Marigómez et al. 2002; Wang and Rainbow 2008). Aquatic invertebrates sharing the same habitat may have very different metal concentrations, depending on their uptake and elimination kinetics, assimilation efficiencies and detoxification strategies 
(Luoma and Rainbow 2008; Wang and Rainbow 2008). A very common means of detoxification in bivalves is the inclusion of metals in insoluble granules or deposits (Mason and Jenkins 1995; Marigómez et al. 2002), which may or may not be excreted. Three types of metal-rich granules are frequently observed within bivalve tissues: copper-, calcium- and ironcontaining granules (Brown 1982). Although all three may be present in bivalve tissues, calcium-containing granules have received the most attention, with descriptions in several tissues, especially in kidney (Sullivan et al. 1988a). The excretory system of bivalves includes the pericardial gland and kidney (nephridium) which is composed of tubular structures (renal tubules) that collect fluids from the pericardial gland and are connected to the excretory pore to excrete the urine.

A histological study performed in 2008 (Darriba et al. 2009) revealed the presence of extracellular granules in the lumen of the renal tubules of all $D$. exoleta individuals examined from the Galician Rías. The present study characterizes and examines the morphological aspects of granular concretions in the kidney tubule lumina of $D$. exoleta by microscopic techniques, and their relation with the high levels of lead accumulation in this species.

\section{Material and methods}

\subsection{Samples}

Dosinia exoleta individuals of uniform size (between 40 and $45 \mathrm{~mm}$ ) were collected from the Galiñeiro natural subtidal bed in the Ría de Arousa (Galicia, NW Spain) in two sampling campaigns in March 2009 and September 2010. Samples were transported to the laboratories in isothermal freezers.

\subsection{Histological and scanning electron microscope analysis}

In March 2009, the kidneys of ten adults were dissected, taking one piece for histological analysis and another for scanning electron microscopy (SEM) analysis and energydispersive X-ray spectroscopy (EDS) from each.

For histological analysis, the kidney samples were fixed in Davidson's solution (Shaw and Battle 1957) and embedded in paraffin. Paraffin blocks were cut into $5-\mu$ m sections with a microtome. Tissue sections were deparaffinized, stained with Harris' hematoxylin and eosin and examined by light microscopy.

For SEM analysis, small pieces of tissue were fixed with $10 \%$ formalin stabilized with methanol and washed in $0.1 \mathrm{M}$ cacodylate buffer with $8 \%$ sucrose, added 4 hours later. Kidney pieces were cut with a blade and shaken on a Petri dish, using dissecting forceps to help to free a high number of kidney granules. Two washes of 1 hour with Mili-Q water were then required to eliminate the cacodylate buffer. Granules were collected using a Pasteur pipette, put on stubs with carbon disc adhesive and dried at $30{ }^{\circ} \mathrm{C}$ until total water evaporation. Finally, the granules were carbon-coated in a Sputter Coater EMITECH K550X by carbon evaporation.
Morphological examination and EDS, for identification of elemental composition, were realized at $20 \mathrm{kV}$ in a Philips XL 30 scanning electron microscope fitted with an EDAX DX4 energy dispersed system. Kidneys embedded in paraffin were also sectioned to obtain a cross section of the granules in the tubule lumina, which was also examined under SEM and analysed by EDS.

\subsection{Metal analysis and subcellular fractionation}

Ten individuals from those collected in March 2009 were dissected to separate the kidney from rest of body and kept frozen in polypropylene vials until digestion and analysis. Metal concentration in the kidneys and the rest of the tissues were measured separately for each individual.

The organisms collected in the second sampling campaign in September 2010 were used for subcellular fractionation of the kidneys. Freshly dissected kidneys from 30 individuals were put into six pre-weighed $10 \mathrm{ml}$ polypropylene vials (five kidneys per vial) and homogenized in 2:1 volume of ultrapure water using a homogenizer (Ultra-Turrax). Homogenized tissue was fractionated using a method modified from Wallace et al. (2003). Briefly, the tissues were centrifuged (15 min; $1400 \mathrm{~g}$ ), the supernatants (cytosol and organelles; S1 fraction) were collected in $10 \mathrm{ml}$ pre-weighed polypropylene vials and the pellets were heated for $2 \mathrm{~min}$ at $100{ }^{\circ} \mathrm{C}$ after addition of $1 \mathrm{ml}$ of ultrapure water. Then, $1 \mathrm{ml}$ of $\mathrm{NaOH} 1 \mathrm{M}$ was added to the pellets and they were heated for $1 \mathrm{~h}$ at $60{ }^{\circ} \mathrm{C}$. After a second centrifugation (10 $\mathrm{min} ; 4600 \mathrm{~g}$ ) the supernatants (cellular debris; S2) were added to the S1 fraction, and the pellets (metal rich granules, MRG) were washed 3 times with $1 \mathrm{ml}$ $\mathrm{NaOH} 1 \mathrm{M}$ and a last time with ultrapure water. The washing solutions (supernatants) were added to the $\mathrm{S} 1+\mathrm{S} 2$ fractions so that two cellular fractions were finally obtained: one containing the granules and the other containing all the rest. The vials were dried to constant weight at $70{ }^{\circ} \mathrm{C}$. Separate kidneys from 25 individuals were individually weighed to establish the relationship between wet and dry weight (dw); the resulting dw: ww ratio for the kidneys was $0.32 \pm 0.08$.

Blank vials were included with the samples to evaluate possible metal contamination during the fractionation procedure.

To assure that the washing of the granules was complete, the quantity of organic carbon remaining in the MRG fraction was measured in a preliminary fractionation test using the wet oxidation method (Walkley 1947) and was found to be lower than $8 \%$.

Metal $(\mathrm{Cu}, \mathrm{Pb}, \mathrm{Zn}$ and $\mathrm{Cd})$ contents of the kidneys, the rest of the clam tissues, the granules and the rest of the kidney tissue were analysed by ICP-MS (X Series, Thermo Elemental, Cheshire, UK) after digestion with $\mathrm{HNO}_{3}$ and $\mathrm{H}_{2} \mathrm{O}_{2}$ following a microwave assisted procedure described elsewhere (Sánchez-Marín and Beiras 2008). Procedure blanks and certified reference material ERM-CE278 (mussel tissue) were included in the sample treatment and analysis. The percentage of recovery of $\mathrm{Cu}, \mathrm{Pb}, \mathrm{Zn}$ and $\mathrm{Cd}$ was between 95 and $105 \%$ in all cases. 


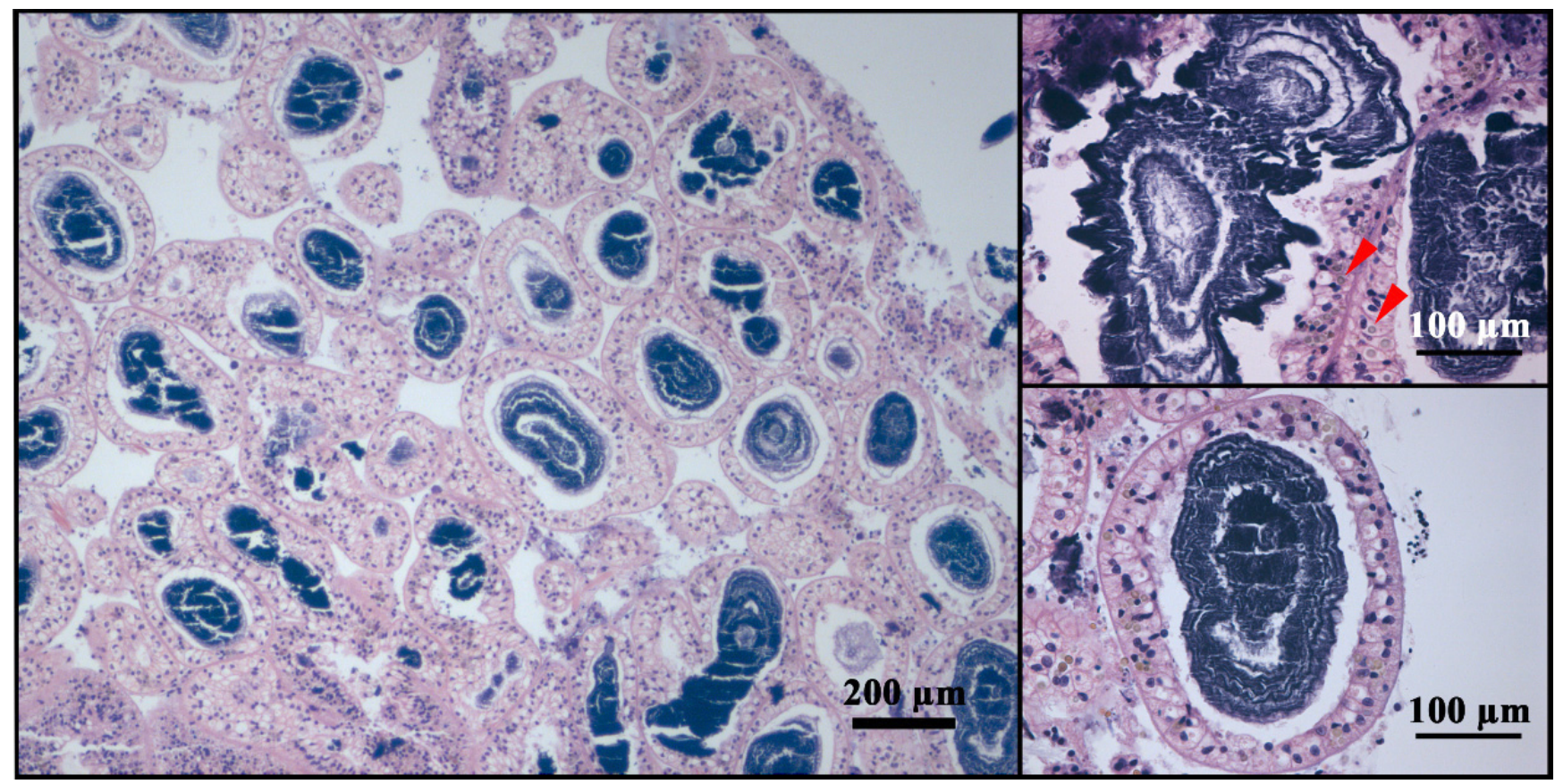

Fig. 1. Kidney lumen of Dosinia exoleta stained with Harris' hematoxylin and eosin observed by light microscope. Large extracellular granules $(20-200 \mu \mathrm{m})$ are stained in blue, and small intracellular refringent granules in epithelial cells are indicated by red arrows.

\section{Results}

\subsection{Histological and scanning electron microscope analysis}

Dosinia exoleta has a large kidney in comparison with other bivalve species, such as mussels or other clams. Wet weight (ww) of dissected kidneys varied between 0.1 and $0.4 \mathrm{~g}$ and represented between $1.5 \%$ and $5 \%$ of the total wet weight of the soft tissues.

Light microscopy showed that kidney tubule lumina were filled with large basophilic extracellular granules of variable sizes $(20-200 \mu \mathrm{m}$ in the large axis) surrounded by epithelial cells. These granules have an irregular shape and are organized in concentric layers around a central core. Most epithelial cells contained small intracellular refringent granules of round shape and brown colour (Fig. 1).

Under the scanning electron microscope, extracellular granules showed variable size and an extremely irregular shape with a dimpled surface (Fig. 2).

$\mathrm{X}$-ray microanalysis revealed that the granules were mainly composed of $\mathrm{Ca}, \mathrm{P}$ and $\mathrm{O}$, with a significant proportion of $\mathrm{Mg}$, and a lower concentration of $\mathrm{Cl}, \mathrm{Na}$ and $\mathrm{Mn}$. The granules are, therefore, mainly formed by $\mathrm{Ca}_{3}\left(\mathrm{PO}_{4}\right)_{2}$ deposits. Other elements, such as $\mathrm{Si}, \mathrm{Zn}$ and $\mathrm{Fe}$ were present in concentrations close to limit of detection of EDS, and were only detected in some of the scans performed, one of which is shown in Figure 3.

\subsection{Metal distribution in the organism}

The ten individuals analysed showed a high variation in their $\mathrm{Pb}$ content. $\mathrm{Pb}$ concentrations in the whole organism varied from 2.0 to $37.0 \mu \mathrm{g} \mathrm{g}^{-1}$ dry weight (dw). Zn concentrations varied by up to an order of magnitude of difference, ranging from 118 to $1151 \mu \mathrm{g} \mathrm{Zn} \mathrm{g}^{-1} \mathrm{dw}$. The concentrations of $\mathrm{Cu}$ and $\mathrm{Cd}$ were more homogeneous, presenting mean concentrations of $4.7 \pm 1.6 \mu \mathrm{g} \mathrm{Cu} \mathrm{g}^{-1} \mathrm{dw}$ and $0.6 \pm 0.15 \mu \mathrm{g} \mathrm{Cd} \mathrm{g}^{-1} \mathrm{dw}$.

Although the kidney was the only organ studied separately, the concentration of the four studied metals was higher there than in the rest of tissues (Table 1). However, this increased tendency for metals to be in the kidney was much more marked for $\mathrm{Pb}$ and $\mathrm{Zn}$ than for the other two metals. Of the total $\mathrm{Pb}$ present in the soft tissues, from 78 to $98 \%$ was found in the kidney. For $\mathrm{Zn}$ this amount varied between $70 \%$ and $97 \%$, while the amount of $\mathrm{Cd}$ and $\mathrm{Cu}$ in this organ represented less than $74 \%$ and $46 \%$ of total body burden, respectively.

\subsection{Metal distribution in the kidney}

The MRG fraction represented between $50 \%$ and $75 \%$ of the dry weight of the kidneys, showing both the high quantity of granules and their relative importance in kidney composition, as can be seen in Figure 1.

The limit of detection of EDS (between 1 and $10 \mathrm{mg} \mathrm{g}^{-1}$ ) was not enough to detect the $\mathrm{Pb}$ concentrations in the granules. $\mathrm{Pb}$ concentration in the MRG fraction measured by ICP-MS was $143 \pm 15 \mu \mathrm{g} \mathrm{g}^{-1} \mathrm{dw}$ (Table 2). $\mathrm{Pb}$ and $\mathrm{Zn}$ concentrations were much higher in the MRG fraction than in the rest of the kidney tissues, while the opposite distribution was observed for $\mathrm{Cu}$ and $\mathrm{Cd}$.

From the total metal contents within the kidney, the majority of $\mathrm{Pb}$ (from $87 \%$ to $92 \%$ ) and $\mathrm{Zn}$ (from $85 \%$ to $91 \%$ ) were in the MRG fraction. In contrast, $\mathrm{Cu}$ and $\mathrm{Cd}$ were preferentially associated with the organic fractions of the kidney. 


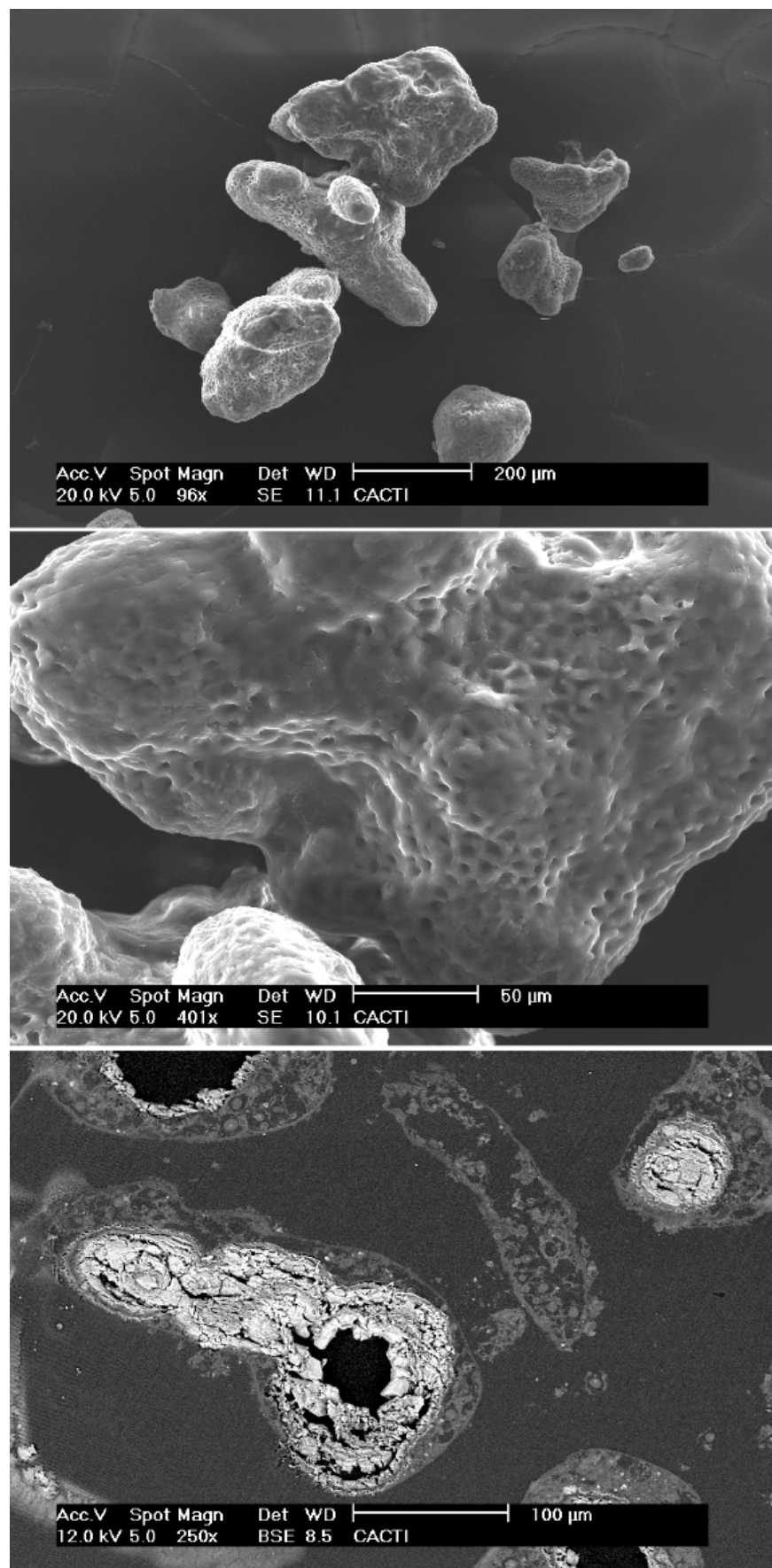

Fig. 2. Scanning electron microscopy images of isolated extracellular granules and a cross section of granules in the kidney lumen.

The fraction of these metals that was present in the granules varied from $2 \%$ to $25 \%$ for $\mathrm{Cu}$ and from $9 \%$ to $12 \%$ for $\mathrm{Cd}$. Mean distribution of four metals within the kidney is represented in Figure 4.

\section{Discussion}

By combining histological and microscope information with metal analysis, it was demonstrated that the reason for

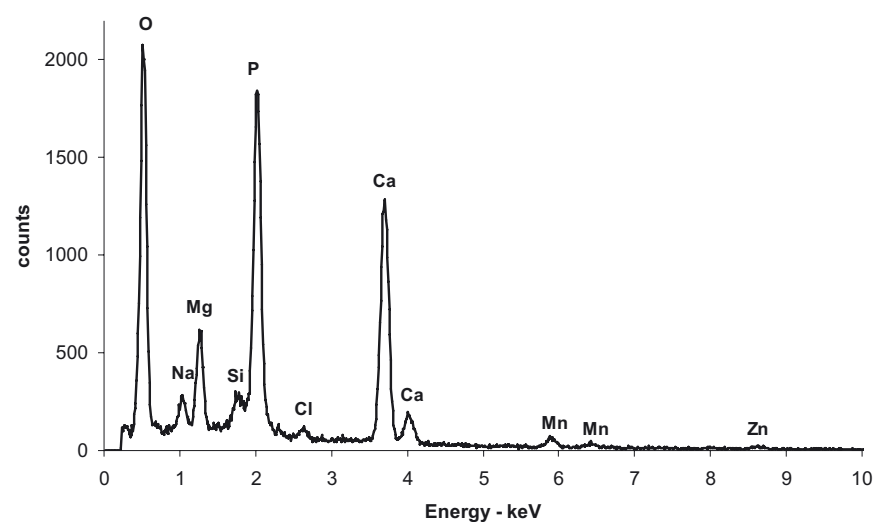

Fig. 3. Energy dispersive X-ray microanalysis of a cross section of a kidney granule showing its main elemental composition.

Table 1. Metal concentrations $\left(\mu \mathrm{g} \mathrm{g}^{-1} \mathrm{dw}\right.$ ) in whole soft tissues of Dosinia exoleta and distribution between the kidney and the rest of the tissues ( $n=10$ individuals).

\begin{tabular}{|c|c|c|c|c|}
\hline & & $\min$ & $\max$ & median \\
\hline \multirow[t]{4}{*}{$\mathrm{Pb}$} & Whole soft tissues & 2.0 & 36.9 & 5.0 \\
\hline & Kidney $^{a}$ & 59.5 & 437.0 & 99.1 \\
\hline & & $(78 \%)$ & $(98 \%)$ & $(92 \%)$ \\
\hline & Rest of tissues & 0.1 & 1.0 & 0.5 \\
\hline \multirow[t]{4}{*}{$\mathrm{Cu}$} & Whole soft tissues & 2.4 & $\overline{7.4}$ & 4.7 \\
\hline & Kidney $^{a}$ & 11.0 & 76.1 & 35.0 \\
\hline & & $(23 \%)$ & $(46 \%)$ & $(35 \%)$ \\
\hline & Rest of tissues & 1.9 & 5.3 & 3.3 \\
\hline \multirow[t]{4}{*}{$\overline{\mathrm{Cd}}$} & Whole soft tissues & 0.3 & 0.8 & 0.6 \\
\hline & Kidney $^{a}$ & 3.3 & 14.9 & 8.0 \\
\hline & & $(52 \%)$ & $(74 \%)$ & $(62 \%)$ \\
\hline & Rest of tissues & 0.1 & 0.4 & 0.2 \\
\hline \multirow[t]{4}{*}{$\mathrm{Zn}$} & Whole soft tissues & 118 & 1151 & 430 \\
\hline & Kidney $^{a}$ & 2761 & 14061 & 8384 \\
\hline & & $(70 \%)$ & $(97 \%)$ & $(89 \%)$ \\
\hline & Rest of tissues & 19.2 & 58.5 & 44.3 \\
\hline
\end{tabular}

${ }^{a}$ The percentage of metal in the kidney was calculated based on the total metal content in the organism's soft tissues.

Table 2. Metal concentrations ( $\left.\mu \mathrm{g} \mathrm{g}^{-1} \mathrm{dw}\right)$ in the subcellular fractions of the kidney metal rich granules (MRG) and the rest of the kidney ${ }^{a}$.

\begin{tabular}{lcccc}
\hline & $\mathrm{Pb}$ & $\mathrm{Cu}$ & $\mathrm{Cd}$ & $\mathrm{Zn}$ \\
\hline MRG & $143 \pm 15$ & $29 \pm 13$ & $2.4 \pm 0.4$ & $7689 \pm 1683$ \\
Rest of & $13 \pm 6$ & $117 \pm 16$ & $16 \pm 4$ & $915 \pm 324$ \\
kidney & & & & \\
\hline
\end{tabular}

${ }^{a}$ Values expressed as the arithmetic mean \pm standard deviation obtained from six composite samples of five kidneys each.

the very high $\mathrm{Pb}$ contents reached in large individuals of $D$. exoleta was the accumulation of $\mathrm{Pb}$ in inorganic concretions in the kidney. $\mathrm{Zn}$ was also found to be strongly associated with the kidney, forming part of the large extracellular calcium phosphate granules present in this organ. For this reason, $\mathrm{Pb}$ and $\mathrm{Zn}$ concentrations were very variable (Table 1), given that the number of granules present in the kidney were also 


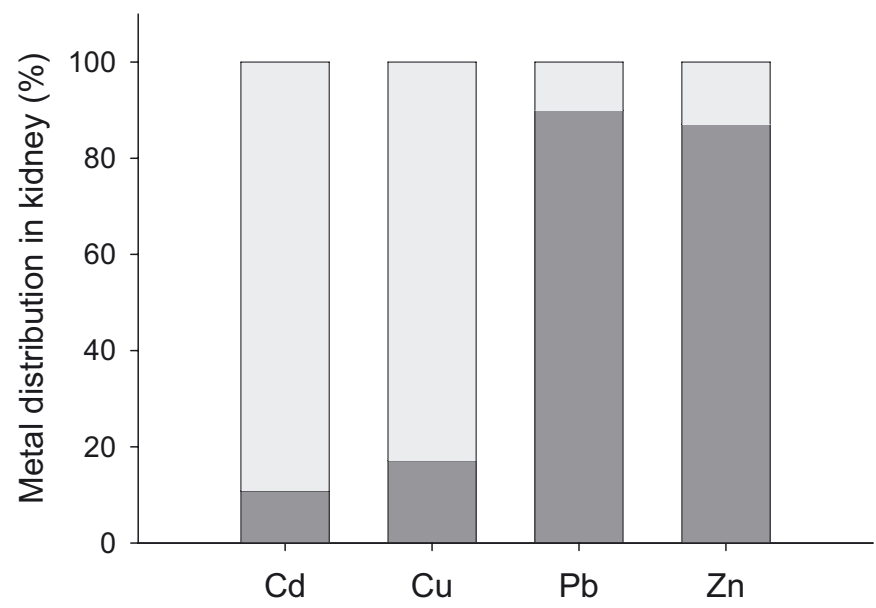

Fig. 4. Mean metal distribution in the kidney of Dosinia exoleta in the MRG (metal rich granules) fraction (dark grey) and the rest of the kidney (light grey). The majority $(>80 \%)$ of $\mathrm{Pb}$ and $\mathrm{Zn}$ were found in the MRG fraction, while only $<20 \%$ of $\mathrm{Cu}$ and $\mathrm{Cd}$ were found in this fraction.

very variable among individuals, as a great heterogeneity in the density of granules occupying the kidney lumen was observed in the several cross sections examined. In contrast, $\mathrm{Cd}$ and $\mathrm{Cu}$ were associated with other tissue fractions, and their concentrations presented less inter-individual variation.

The granules described here correspond to type B calciumcontaining granules, according to the classification in Brown (1982). These granules are described as containing low purity calcium, i.e., together with magnesium, manganese, phosphorus and perhaps other metals. This type of granules, as opposed to the type A calcium-containing granules - believed to have mainly a calcium storage function-, have more dynamic functions such as excretion, storage and calcium mobilization, and/or detoxification. In a different classification made by Hopkin (1989), these same low purity calcium granules are named "Type A granules" and are known to be able to accumulate potentially toxic class A and borderline metals such as $\mathrm{Mn}, \mathrm{Zn}$ and $\mathrm{Pb}$, while class $\mathrm{B}$ metals such as $\mathrm{Cd}, \mathrm{Cu}$ and $\mathrm{Hg}$ have not been detected in them. This agrees with our finding that $\mathrm{Pb}$ and $\mathrm{Zn}$ are preferentially found in the granules, while $\mathrm{Cu}$ and $\mathrm{Cd}$ are not, combined with the presence of significant Mn concentrations in the granules, which are high enough to be detected with EDS (Fig. 3). However, Hopkin (1989) describes type A granules as being intracellular, while the granules described here are extracellular. This is probably the result of intracellular granules being excreted into the kidney lumen, where aggregation of smaller granules or layering of intraluminal material in concentric rings would lead to the formation of extracellular kidney granules, as described in Marigómez et al. (2002). It is likely that bivalve kidney granule production and subsequent increase in size is a continuous process of lysosomal maturation, residual body release and extracellular accumulation (Sullivan et al. 1988a).

The presence of larger granules in some species is believed to reflect a longer residence in the kidney lumen and concomitant acquisition of materials, although it is not known why granules are retained and continue to grow in the kidney in some species, while in others they are quickly excreted (Sullivan et al. 1988a; Marigómez et al. 2002). Given the large size reached by the granules found in $D$. exoleta, and the relationship of $\mathrm{Pb}$ concentration with animal size (SánchezMarín and Beiras 2008), it is probable that this species retains all the granules it produces or that their excretion is very limited. Gold et al. (1982) found that the largest specimens of $M$. mercenaria had significantly higher amounts of kidney concretions than either intermediate or small clams, again suggesting a relationship between age and accumulation of granules. Also, the size of the kidney seems to play a role in granule production: bivalve species showing "kidney gigantism" have been shown to produce very large quantities of extracellular metal-sequestering granules compared with species that have normal kidneys (Reid and Brand 1989).

Large, extracellular kidney granules, similar to the ones described here, have been observed in several bivalves including Pinna nobilis (Ghiretti et al. 1972), Macrocallista nimbosa (Tiffany et al. 1980), Donax trunculus (Mauri and Orlando 1982), Cyclosunetta menstrualis (Ishii et al. 1986), Mercenaria mercenaria (Sullivan et al. 1988a) and Donacilla cornea (Regoli et al. 1992). In most cases, these granules were shown to contain high Mn concentrations, although some other trace metals were also detected, such as $\mathrm{Fe}, \mathrm{Zn}$ and $\mathrm{Pb}$. Sullivan et al. (1988a) reported $\mathrm{Pb}$ concentrations in kidney granules from $M$. mercenaria at around $150-200 \mu \mathrm{g} \mathrm{g}^{-1} \mathrm{dw}$, similar to those observed in D. exoleta $\left(146 \pm 16 \mu \mathrm{g} \mathrm{g}^{-1} \mathrm{dw}\right)$. Subcellular distribution in the kidney also showed that these metals were mainly associated with concretions, while $\mathrm{Cu}$ and $\mathrm{Cd}$ were associated with the cytosolic fraction in M. mercenaria (Sullivan et al. 1988b).

It is not clear if the formation of renal concretions in bivalves has a detoxification role or another biological function, although it has been proposed that the excretion of concretions to the kidney lumen in some molluscs is a mechanism that contributes to the elimination of certain metals (Mason and Jenkins 1995; Marigómez et al. 2002). Mauri and Orlando (1982) observed that D. trunculus presented fewer renal concretions in relatively unpolluted waters than in highly polluted waters and that the formation of renal concretions in naturally concretion-free clams could be induced by exposing them to high $\mathrm{Mn}$ concentrations in the surrounding water. However, renal concretions containing heavy metals are also found in bivalve populations in apparently unpolluted waters. This suggests that factors other than high metal concentrations may induce their formation. According to Doyle et al. (1978), renal concretions appear to be a normal formation of the excretory process of some molluscs under reproductive, environmental, or pollutant-induced stress. This type of renal concretions might have evolved as a system involved in calcium homeostasis, to eliminate excess ionic calcium from the cells (Simkiss 1977), and the inclusion of other metals in their composition might be a secondary function (Mason and Jenkins 1995). Interestingly, induction of renal concretions was observed after exposure of D. cornea to sublethal concentrations of $\mathrm{Cu}$ and $\mathrm{Cd}$ (Regoli et al. 1992), but $\mathrm{Cu}$ and $\mathrm{Cd}$ were not detected in the concretions. According to these authors, the presence of these metals may have interfered with Ca metabolism (disrupting the 
plasma membrane Ca-extruding systems) and the formation of renal concretions was activated to eliminate calcium excess.

In the case of $D$. exoleta, there is not enough data at present to determine wether the formation of kidney granules is induced by external factors, such as metal pollution, or not. The Galician Rías present a low to moderate degree of pollution, restricted to localized areas (Beiras et al. 2003b; Prego and Cobelo-García 2003), and Mn levels are not particularly high, and comparable to natural reference levels in other parts of the world (Prego and Cobelo-García 2003). Granules have been observed in the kidneys of individuals from other populations in other Galician Rías (unpublished data); and high levels of $\mathrm{Pb}$ have been detected in all analysed populations in the Galician Rías. This information may indicate that kidney granule formation and maturation may be a general process in D. exoleta, and in larger - and older- individuals, resulting in high $\mathrm{Pb}$ body burdens. Given the large size of the kidney in this species, which would make a high granule content possible, if $\mathrm{Pb}$ is never excreted from the body, then even not very elevated $\mathrm{Pb}$ concentrations in the environment could lead to final $\mathrm{Pb}$ body burdens over the safety limit for human consumption.

Acknowledgements. We gratefully acknowledge Belén Alonso, Loli Amo, Soledad Bastos, Belén Alonso and Juana Marchena of INTECMAR and Marta Miñambres of ECIMAT for technical assistance; Jesús Mendez and Inés Pazos of CACTI for assistance with scanning electron microscopy; Leticia Vidal for her help in the subcellular fractionation and David Iglesias for his contribution to the first detection of the granules. Microanalysis and metal analysis were performed in the CACTI, University of Vigo. Subcellular distribution was done at the ECIMAT, University of Vigo. This study was partially financed by Spanish Ministry of Science and Innovation through the Research Project CTM2009-10908 and by Technological Institute for the Monitoring of the Marine Environment of Galicia (INTECMAR).

\section{References}

Anonymous, 2006, Commission Regulation (EC) No 1881/2006 of 19 December 2006 setting maximum levels for certain contaminants in foodstuffs. Official Journal of the European Communities, L364, 524.

Anonymous, 2012, Xunta de Galicia, Consellería do Mar. Retrieved 5 June 2012, from http://www.pescadegalicia.com/default.htm.

Beiras R., Bellas J., Fernández N., Lorenzo J.I., Cobelo-García A., 2003a, Assessment of coastal marine pollution in Galicia (NW Iberian Peninsula); metal concentrations in seawater, sediments and mussels (Mytilus galloprovincialis) versus embryolarval bioassays using Paracentrotus lividus and Ciona intestinalis. Mar. Environ. Res. 56, 531-553.

Beiras R., Fernández N., Bellas J., Besada V., González-Quijano A., Nunes T., 2003b, Integrative assessment of marine pollution in Galician estuaries using sediment chemistry, mussel bioaccumulation, and embryo-larval toxicity bioassays. Chemosphere 52, $1209-1224$.

Beiras R., Fernández N., Pombar L., 2003c, Metal accumulation in wild intertidal mussels from the Galician rías. In: Villalba A., Reguera B., Romalde J.L., Beiras R. (Eds.) Proc. 4th International Conference on Molluscan Shellfish Safety. Santiago de Compostela, 2002. Consellería de Pesca e Asuntos Marítimos, Xunta de Galicia. IOC-Unesco, pp. 521-532.
Besada V., Fumega J., Vaamonde A., 2002, Temporal trends of Cd, $\mathrm{Cu}, \mathrm{Hg}, \mathrm{Pb}$ and $\mathrm{Zn}$ in mussel (Mytilus galloprovincialis) from the Spanish North-Atlantic coast 1991-1999. Sci. Tot. Environ. 288, 239-253.

Besada V., González-Quijano A., 2003, Levels of heavy metals and organochloninre compounds in cockles (Cerastoderma edule) in the Ría de Vigo. In: Villalba A., Reguera B., Romalde J.L., Beiras R. (Eds.) Proc. 4th International Conference on Molluscan Shellfish Safety, Santiago de Compostela, 2002. Consellería de Pesca e Asuntos Marítimos, Xunta de Galicia. IOC-Unesco, pp. 545-553.

Besada V., Manuel Andrade J., Schultze F., José González J., 2011, Monitoring of heavy metals in wild mussels (Mytilus galloprovincialis) from the Spanish North-Atlantic coast. Cont. Shelf Res. 31, 457-465.

Blanco S.L., González J.C., Vieites J.M., 2008, Mercury, cadmium and lead levels in samples of the main traded fish and shellfish species in Galicia, Spain. Food Addit. Contam. B 1, 15-21.

Brown B.E., 1982, The form and function of metal-containing "granules" in invertebrate tissues. Biol. Rev. 57, 621-667.

Darriba S., Iglesias D., Rodríguez L., 2009, Estudio histológico de seguimiento del reloj (Dosinia exoleta) (Mollusca, Bivalvia) en la Ría de Arousa: Resultados preliminares. In: Troncoso J.S., Alejo I., López J. (Eds.) Proc. ISMS09. II International symposium in Marine Sciences. Universidade de Vigo, pp. 80-81.

Doyle L.J., Blake N.J., Woo C.C., Yevich P., 1978, Recent biogenic phosphorite: concretions in mollusk kidneys. Science 199, 1431-1433.

Ghiretti F., Salvato B., Carlucci S., De Pieri R., 1972, Manganese in Pinna nobilis. Experientia 28, 232-233.

Gold K., Capriulo G., Keeling K., 1982, Variability in the calciumphosphate concretion load in the kidney of Mercenaria mercenaria. Mar. Ecol. Prog. Ser. 10, 97-99.

Hopkin S.P., 1989, Ecophysiology of metals in terrestrial invertebrates. Essex, Elsevier.

Ishii T., Ikuta K., Otake T., Hara M., Ishikawa M., Koyanagi T., 1986, High accumulation of elements in the kidney of the marine bivalve, Cyclosunetta menstrualis. Bull. Jpn. Soc. Sci. Fish. 52, $147-154$.

Luoma S.N., Rainbow P.S., 2008, Metal Contamination in Aquatic Environments: Science and Lateral Management. New York, Cambridge University Press.

Marigómez I., Soto M., Cajaraville M.P., Angulo E., Giamberini L., 2002, Cellular and subcellular distribution of metals in molluscs. Microsc. Res. Techn. 56, 358-392.

Mason A.Z., Jenkins K.D., 1995, Metal detoxification in aquatic organisms. In: Tessier A., Turner D.R. (Eds.) Metal Speciation and Bioavailability in Aquatic Systems. Wiley, pp. 479-607.

Mauri M., Orlando E., 1982, Experimental study on renal concretions in the wedge shell Donax trunculus L. J. Exp. Mar. Biol. Ecol. 63, 47-57.

Prego R., Cobelo-García A., 2003, Twentieth century overview of heavy metals in the Galician Rias (NW Iberian Peninsula). Environ. Pollut. 121, 425-452.

Regoli F., Nigro M., Orlando E., 1992, Effects of copper and cadmium on the presence of renal concretions in the bivalve Donacilla cornea. Comp. Biochem. Physiol. C 102, 189-192.

Reid R.G.B., Brand D.G., 1989, Giant kidneys and metalsequestering nephroliths in the bivalve Pinna bicolor, with comparative notes on Atrina vexillum (Pinnidae). J. Exp. Mar. Biol. Ecol. 126, 95-117.

Saavedra Y., González A., Fernández P., Blanco J., 2004, Interspecific variation of metal concentrations in three bivalve mollusks from Galicia. Arch. Environ. Contam. Toxicol. 47, 341-351. 
Sánchez-Marín P., Beiras R., 2008, Lead concentrations and size dependence of lead accumulation in the clam Dosinia exoleta from shellfish extraction areas in the Galician Rías (NW Spain). Aquat. Living Resour. 21, 57-61.

Shaw, B.L., Battle, H.I., 1957. The gross and microscopic anatomy of the digestive tract of the oyster Crassostrea virginica (Gmelin). Can. J. Zool. 35, 325-347.

Simkiss K., 1977, Biomineralization and detoxification. Calcified Tissue Int. 24, 199-200.

Sullivan P.A., Robinson W.E., Morse M.P., 1988a, Isolation and characterization of granules from the kidney of the bivalve Mercenaria mercenaria. Mar. Biol. 99, 359-368.

Sullivan P.A., Robinson W.E., Morse M.P., 1988b, Subcellular distribution of metals within the kidney of the bivalve Mercenaria mercenaria (L.). Comp. Biochem. Physiol. C 91, 589-595.
Tiffany W.J., Luer W.H., Watkins M.A., 1980, Intracellular and intraluminal aspects of renal calculosis in the marine mollusc Macrocallista nimbosa. Invest. Urol. 18, 139-143.

Walkley A., 1947, A critical examination of a rapid method for determining organic carbon in soils: Effect of variations in digestion conditions and of inorganic soil constituents. Soil Sci. 63, 251-264.

Wallace W.G., Lee B.G., Luoma S.N., 2003, Subcellular compartmentalization of $\mathrm{Cd}$ and $\mathrm{Zn}$ in two bivalves. I. Significance of metal-sensitive fractions (MSF) and biologically detoxified metal (BDM). Mar. Ecol. Prog. Ser. 249, 183-197.

Wang W.X., Rainbow P.S., 2008, Comparative approaches to understand metal bioaccumulation in aquatic animals. Comp. Biochem. Physiol. C 148, 315-323. 